\title{
BETWEEN THE BIOACTIVE EXTRACTS OF EDIBLE MUSHROOMS AND PHARMACOLOGICALLY IMPORTANT NANOPARTICLES: NEED FOR THE INVESTIGATION OF A SYNERGISTIC COMBINATION - A MINI REVIEW
}

\author{
UKAEGBU CHINONSO ISHMAEL ${ }^{1 *}$, SHAH SAMIUR RASHID ${ }^{1,3}$, Jalal K C A $^{2}$, SHAHEEN SARKAR ${ }^{1}$, \\ HAZRULRIZAWATI ABD HAMID ${ }^{1}$, AZMI N S ${ }^{1}$
}

\begin{abstract}
${ }^{1}$ Faculty of Industrial Sciences and Technology, Universiti Malaysia Pahang, Malaysia. ${ }^{2}$ Institute of Oceanography and Maritime Studies, Kulliyyah of Science, International Islamic University Malaysia, Malaysia. ${ }^{3}$ Centre for Bio-composites and Innovative Materials, Universiti Malaysia Pahang, Lebuhraya Tun Razak, 26300 Gambang Kuantan, Pahang, Malaysia. Email: chinoreal1456@yahoo.com
\end{abstract}

Received: 27 September 2016, Revised and Accepted: 27 January 2017

\section{ABSTRACT}

The pharmacological potential of bioactive compounds extracted from mushrooms has been studied to a reasonable level. In the same vein, the bioactivity of nanoparticles has also been investigated and reported to be of potential pharmacological benefit. No doubt, there is a reasonable amount of claims regarding the vast activity of the mushroom extracts and nanoparticles on the tested cell lines and microorganisms. In this paper, a review of the recent application of bioactive compounds extracted from two edible mushrooms (Coprinus comatus and Lactarius deliciosus), as well as some of the recently reported studies on some nanoparticles of pharmacological potentials, was carried out. In order to check for synergy in the bioactivity of the mushroom extracts when co-administered with nanoparticles, an investigation on the synergistic application of the materials through the encapsulation of the bioactive extracts from the mushroom onto the nanoparticle was proposed. The supposed synergy in the activity of the extract-nanoparticle complex could hold the key to improved activity of nutraceuticals against resistant microorganisms and tumor cells.

Keywords: Coprinus comatus, Lactarius deliciosus, Nanoparticles, Synergy, Bioactive extracts.

(c) 2017 The Authors. Published by Innovare Academic Sciences Pvt Ltd. This is an open access article under the CC BY license (http://creativecommons. org/licenses/by/4.0/) DOI: http://dx.doi.org/10.22159/ajpcr.2017.v10i3.15406

\section{INTRODUCTION}

In the days and even presently, mushrooms are consumed all over the world by people for their nutritional and culinary potentials. Due to the high protein, low fat, and cholesterol contents of mushrooms, they are considered by many people to be a vital component of daily meals as a source of nutritional ingredients such as minerals, polysaccharides, flavonoids, and polyphenols [1]. Some polyphenolic compounds derived from mushrooms have been found to possess powerful antioxidant activities, with free radical scavenging and metal chelating activities [2]. Recent researches provide consistent approval for the development of ethnomedicine [3]. More evidence has been provided using bioactive materials extracted from mushrooms [4], as well as polysaccharides isolated from Ganoderma lucidum and Trametes versicolor [5], which showed great expression of tumor markers [4], increased natural killer cells activities, and higher survival rate [5]. Following the successful trials, polysaccharides isolated from T. versicolor had further been approved in Japan and marketed as an antitumor drug known as Krestin (PSK). Further utilization of the pharmacological potentials of natural materials could be the key to solving the emerging challenges of new diseases and drug-resistant variants.

The current emergence of the superbug, increased cancer epidemics and multidrug-resistant bacteria strains is pushing for an urgent need in the provision of antibacterial compounds that could be novel enough to combat the threat of these organisms. As a result of mushrooms' natural living environment (life cycles which depend on degrading dead organic matters) and the need to defend against pathogenic organisms in their environment, it is believed that potent antimicrobial and cytotoxic compounds could be extracted from mushrooms [6]. This prospect is supported by a previously reported case, whereby antimicrobial farnesyl hydroquinones (ganomycin A and B) isolated from Ganoderma pfeifferi were found to inhibit the growth of methicillin-resistant Staphylococcus aureus [7].
With this supporting evidence, it is certain that work has previously been done on the cytotoxicity of bioactive substances extracted from Coprinus comatus and Lactarius deliciosus. However, it could be interesting to extend the present knowledge on the pharmacological properties of these bioactive compounds from C. comatus and L. deliciosus by studying the cyto-effects when coupled on a nanoparticle with pharmacological potentials. Some nanomaterials have been synthesized in a nanoscale $(<100 \mu \mathrm{m})$ and a handful of these materials tested against notable human cell line for cytotoxic and antibacterial activities. Among the nanomaterials synthesized and tested were sulfated zirconia nanoparticles, cerium, single-walled carbon nanotubes (SWCNTs) to mention but a few [8]. Although nanoparticles are most suitable for delivering of hydrophobic drugs, several reports have shown success in encapsulating hydrophilic drugs through surface attachment or polymer drug conjugation methods [9]. Many approaches have also been taken to co-encapsulate multiple therapeutic agents into a single polymeric nanoparticle. Drugs can be attached to the nanoparticles using either of the following ways:

a. Direct encapsulation of drugs into the hydrophobic polymeric core of the nanoparticle

b. Incorporation of an additional medium to the nanoparticle, usually on the particle surface to create a separate partition for drug loading

c. Covalent conjugation of drugs to the polymer backbone during the synthesis of the nanoparticle.

Hence, in this article, a mini review of the current studies on two edible mushrooms ( $C$. comatus and L. deliciosus) as well as a review of selected nanoparticles of pharmacological interest was conducted. The recent applications of the bioactive compounds extracted from the selected mushrooms, as well as the application of nanoparticles for pharmacological benefits, were carried out. At the end of the review, a proposal for the synergistic utilization of the bioactive compounds extracted from the mushrooms, together with the nanoparticles for an improved antibacterial and antitumor activity against selected microorganisms and tumor cells, was made. 


\section{MUSHROOMS}

Mushrooms, also known as toadstools, are group(s) of the fleshy, sporeproducing, and fruiting body of fungi, commonly springing from the ground or on the food source where they grow as saprophytes. Generally, mushrooms are commonly identified through the application of the basic understanding of their macroscopic features. Most mushrooms are classified as Basidiomycetes, with characteristic possession of much-developed gills, which are arranged in a room-like pattern. Mushrooms possess spores (basidiospores) which are produced on the gills and when matured fall off in a fine rain manner from the underside of the caps, facilitating its dispersals [10]. Typically, mushrooms are the fruit bodies of the order Agaricales, but with the evolution of molecular classification, not all the members of this order can produce the typical fruit bodies but possess gills, placing them in the class Agaricomycetes. For instance, the milk cap mushrooms (Lactarius and Lactifluus) and russulas (Russula), as well as Lentinellus, belong to the Russulales [2].

Mushrooms can be grouped as edible or poisonous, suggesting that mushroom may be eaten, toxic, or unpalatable with the human body. The edible mushrooms are cultivated in controlled (or wild) environment for human consumption owing to their low caloric content and abundance of bioactive compounds which are beneficial to human health. The poisonous (toxic) mushrooms are known to contain substances which are toxic to the human body when eaten. Most of the toxins are believed to possess neurotoxic, nephrotoxic, hepatotoxic, as well as psychotic effects [11]. Medicinally, mushrooms possess bioactive compounds which have been studied and documented as potential sources of nutraceuticals owing to their potency against reactive oxygen species (ROS) and tumor cell inhibition. Mushrooms also possess antimicrobial activities which have been effective against the Gram-positive and the Gram-negative bacteria $[2,12]$. The ability of mushroom farmers to cultivate some of the medicinal mushrooms in commercial quantity has boosted the recent advances toward the utilization of the bioactive compounds from mushrooms for pharmacological and therapeutic purposes. Within the scope of this research, a critical review will be focused on two identified medicinal mushrooms ( $L$. deliciosus and C. comatus). The review will focus on the geographical location (habitat), the nutritional benefits, the pharmacological importance of the bioactive compounds, and the economic importance of the discussed mushrooms.

Clinical evidence of mushroom extracts as pharmacological agents Various mushroom polysaccharides have gone into clinical trials in cancer patients, most of which, however, have just been studied in nonrandomized trials with a small number of patients. These trials have been carried out exclusively in the Far East although some have already begun in the United States. Safety during clinical assessments has been good, with no maximum tolerated dose for these compounds currently reached, and making the potential of a prolonged use of these compounds without side effects a possibility. Griffon-D, a mushroom-based product, has recently been excluded from Phase I study by the FDA because of the lack of preclinical toxicity. Even though some of these mushroom compounds have not been tried in the Western standard randomized trials, there are strong proof-of-principle data for some medicinal mushrooms to support further studies [13]. Trials with compounds isolated from Agaricus bisporus $[14,15]$ and some species of Pleurotus [16] have shown both in vitro and in vivo anti-inflammatory activities, whereas extracts from $L$. deliciosus have also been put to clinical trials.

Methanol extracts of L. deliciosus have been tested to assess the potential anti-inflammatory activity of the mushroom using macrophages RAW 264.7 by Moro et al., who reported that the extracts were able to affect the viability of the cells, except at a lower concentration of $0.5 \mathrm{mg} / \mathrm{mL}$ [14]. This report was supported by a bar chart presenting a comparative study of six mushrooms (A. bisporus, Boletus edulis, Cantharellus cibarius, Craterellus cornucopioides, L. deliciosus, and Pleurotus ostreatus) with the conventional anti-inflammatory agent, lipopolysaccharide (LPS). The data showed that L. deliciosus portrayed the highest anti-inflammatory activity against the macrophages and stood to argue that the high total phenolic content of the L. deliciosus could be a reason for its strong anti-inflammatory activity [14]. The ability of the bioactive extracts of $L$. deliciosus has also been tested for its ability to stimulate the production of nitric oxide (NO) (a substance produced by macrophages when stimulated). The macrophages were incubated with the extracts for $1 \mathrm{hr}$ and later stimulated with LPS $(1 \mu \mathrm{g} / \mathrm{mL})$ for $24 \mathrm{hrs}$, and the level of NO release was measured by the accumulation of the metabolite nitrite in the culture supernatant. The macrophages that were not stimulated were found to produce no NO, while those stimulated with the LPS presented a high level of NO production [14]. The results showed that extracts from some of the mushrooms studied inhibited LPS-induced NO production and the expression of proinflammatory cytokines, such as interleukin-1b (IL-1b) and IL-6. The overproduction of these mediators has been implicated in various inflammatory diseases and cancer [17]. The inhibition of the activation of these mediators seems to be an important target for the treatment of inflammatory diseases. The most efficient species among the studied species were $C$. cibarius, L. deliciosus, and A. bisporus while others such as B. edulis and P. ostreatus had no effect [18].

Although many natural substances may take part in anti-inflammatory activities, phenolic compounds have been recognized as natural molecules with most potent anti-inflammatory effects. Positive correlations have been established between total phenolic content and anti-inflammatory effects of different mushroom extracts $[19,20]$. Phenolic compounds consist of a range of substances which display a great diversity of structures and their biological activity may be highly influenced by the chemical nature of the components. Even though phenolic acids are the most abundant compounds in most mushroom species, their content may not correlate with the inhibitory potential of the extracts and stands to reason that the contribution of these compounds to the anti-inflammatory activity is not relevant.

To justify this, studies carried out to establish the effect of derivatives on the production of inflammatory agents concluded that derivatives, such as caffeic acid, ferulic acid, chlorogenic acid, and p-hydroxybenzoic acid, from an ethanolic plant extract, did not affect the production inflammatory agents [21]. Furthermore, pyrogallol, which is present in extracts of A. bisporus, C. cibarius, C. cornucopioides, and L. deliciosus [14], may be responsible for the anti-inflammatory activity observed in the extracts of these mushrooms since these extracts were the most active in terms of NO inhibition. Synergisms between pyrogallol and other active compounds present in the extracts from L. deliciosus, and other studied mushrooms such as flavonoids or cinnamic acid derivatives could partly explain the differences in activity of the studied extracts [14].

\section{DELICIOSUS}

L. deliciosus, best known as the saffron milk cap or red pine mushroom, belongs to the genus Lactarius and order Russulales. It is among the best-known members of the large milk cap mushrooms found mainly in Europe and but accidentally has been introduced to other countries. It can be found growing in pine plantations and related environments where the environment is favorable [22]. L. deliciosus possesses a carrot orange cap, which is convex to vase-shaped. When young, it is in-rolled, measuring about 4-14 cm (1.5-5.5 inch) in diameter, usually with darker orange lines arranged in concentric circles. The cap is viscous and sticky when wet although it is often dry. The gills are crowded and decurrent with a squat hollow orange stipe often measuring $3-8 \mathrm{~cm}$ (1-3 inch) in length and about $1-2 \mathrm{~cm}(0.5-1 \mathrm{inch})$ in thickness. When handled, L. deliciosus stains with a deep green color; however, when fresh, the mushroom produces orange-red "milk" which does not change color [22]. Mycologically, L. deliciosus possesses gills on the hymenium and has a depressed cap, hymenium is decurrent, stipe is bare, spore print is tan, and ecology is mycorrhizal, while edibility is purely on choice.

\section{Nutritional benefits of $L$. deliciosus}

The major compounds found in mushrooms are carbohydrates and proteins. Total protein content varying between $21 \%$ and $50 \%$ has been reported, which competed with protein from meat, milk, and egg. 
Mushrooms are also consumed due to their low-calorie content (1.40-10.58\%) [23]. Analysis of the chemical composition of L. deliciosus showed that it contained $8.75 \%, 2.64 \%, 75.25 \%$, and $4.61 \%$ of moisture, fat, protein, and ash, respectively, representing approximately $89.96 \%$ of the total dry material [24]. Although similarities in the composition of mushrooms exist, the chemical composition of mushrooms is usually affected by a number of factors, which includes mushroom strains, growth media composition, environment, harvesting time, handling conditions, and substrates preparation. There is diversity in the antimicrobial and antitumor activity of mushrooms at different stages of cultivation of the same species due to changes in the content and amount of active compounds according to the growth media and environment of the mushroom [25].

Wild edible mushrooms such as L. deliciosus are popular food stuff with reported high levels of proteins, zinc, vitamins, iron, sodium, and minerals, which could be a major component of the mushroom or could be absorbed from the surrounding environment. This could be the reason for a higher composition of minerals and chemicals in wild mushrooms [26]. Because mushrooms aid in the breakdown of organic matter and play a role in the natural decomposition of materials, a very effective mechanism for the accumulation of heavy metals from the environment persists in mushrooms, especially the wild mushrooms [27]. These metals are part of the nutritional benefits from mushrooms since most of the metals act as cofactors for most of the complex enzyme systems.

\section{Pharmacological potentials of $L$. deliciosus}

Pharmacologically, the application of mushroom extracts in medicine has been researched and various reports have been documented regarding the health benefits of extracts from the mushroom. In pharmacological trials, bioactive compounds from $L$. deliciosus have been tested against a wide range of bacteria and tumor cells owing to their radical scavenging properties and phenolic content $[12,28]$. Jayakumar et al. reported that wild mushrooms can be used for therapeutic purposes because they produce varieties of metabolites, such as organic acids, terpenoids, alkaloids, and phenolic and steroid compounds [29]. Health beneficial properties, such as antioxidant, antimicrobial, anticancer, cholesterollowering activities, and immune stimulatory effects, have all been reported for species of mushrooms including L. deliciosus [12,28].

The radical scavenging properties and the total phenolic content of L. deliciosus have been studied by various researchers and compared with other wild and cultivated mushrooms. The results of the previous studies on L. deliciosus compared with other mushrooms are presented in Table 1.

Table 1: Radical scavenging and phenolic content of selected mushrooms

\begin{tabular}{|c|c|c|c|}
\hline Mushroom & $\begin{array}{l}\text { DPPH } \\
\text { radical } \\
\text { scavenging }\end{array}$ & Phenolic content & References \\
\hline $\begin{array}{l}\text { Lactarius } \\
\text { deliciosus }\end{array}$ & $\begin{array}{l}493.82 \pm 2.35 \\
\left(\mathrm{IC}_{50} \mu \mathrm{g} / \mathrm{mL}\right) \\
34.48 \pm 4.34 \\
\left(\mathrm{IC}_{50} \mu \mathrm{g} / \mathrm{mL}\right) \\
0.210 \pm 0.006 \\
(500 \mu \mathrm{g} / \mathrm{mL}) \\
\mathrm{Nd}\end{array}$ & $\begin{array}{l}42.68 \pm 1.065 \\
\text { ( } \mu \mathrm{g} \mathrm{PE} / \mathrm{mg} \text { of extract) } \\
17.25 \pm 0.65 \\
(\mu \mathrm{g} \mathrm{PE} / \mathrm{mg} \text { of extract) } \\
12.75 \pm 0.38 \\
(\mathrm{mg} \mathrm{PE} / \mathrm{g} \text { dry weight) } \\
17.25 \pm 0.65 \\
(\mathrm{mg} / \mathrm{g})\end{array}$ & $\begin{array}{l}{[27]} \\
{[30]} \\
{[31]} \\
{[1]}\end{array}$ \\
\hline $\begin{array}{l}\text { Macrolepiota } \\
\text { procera }\end{array}$ & $\begin{array}{l}311.40 \pm 1.28 \\
\left(\mathrm{IC}_{50} \mu \mathrm{g} / \mathrm{mL}\right) \\
69.74 \pm 0.65 \\
(500 \mu \mathrm{g} / \mathrm{mL})\end{array}$ & $\begin{array}{l}67.98 \pm 1.013 \\
\text { ( } \mu \mathrm{g} \mathrm{PE} / \mathrm{mg} \text { of extract) } \\
8.90 \pm 0.10 \\
\text { (mg PE/g dry weight) }\end{array}$ & $\begin{array}{l}{[27]} \\
{[31]}\end{array}$ \\
\hline $\begin{array}{l}\text { Cantharellus } \\
\text { cibarius }\end{array}$ & $\begin{array}{l}56.34 \pm 0.05 \\
(500 \mu \mathrm{g} / \mathrm{mL})\end{array}$ & $\begin{array}{l}0.69 \pm 0.20 \\
\text { (mg PE/g dry weight) }\end{array}$ & {$[31]$} \\
\hline
\end{tabular}

Nd: Not determined, DPPH: 1, 1-diphenyl-2-picryl-hydrazil
The rate of antioxidant activity depends on the mushroom species and also on the solvent used for extraction. Various reports suggested that the radical scavenging activities of most extracts depend on the total phenolic content as extracts with higher total phenolic were seen to possess high radical scavenging properties $[12,32,33]$.

L. deliciosus is an important source of natural antioxidants such as phenolic compounds (tocopherols, flavonoids, and phenolic acids), nitrogen compounds (alkaloids, amino acids chlorophyll derivatives, and amines), or carotenoids as well as ascorbic acid. These are molecules produced as secondary metabolites with great therapeutics effects. The consumption natural foods such as mushroom provide supplements and antioxidants which help to protect the body against various diseases, such as cancer, heart, and cerebrovascular diseases. They may also help the human body in reducing oxidative damage or protect oxidative deterioration, usually develop as a result of stress. Both the fruiting body and the mycelium of $L$. deliciosus contain compounds which exhibit both antioxidant and antimicrobial activities. Specific compounds are extracted to produce antibiotic or pharmaceutical drugs for combating various forms of diseases [25,31].

Due to the high polyphenol content of $L$. deliciosus, it has been reported by Elmastas et al. to be superior in anthocyanin content (1.38 $\pm 0.09 \mathrm{mg}$ cyaniding 3 -glucoside/g dry weight) among 12 screened mushroom species and this conferred a great pharmacological activity on L. deliciosus [31]. The radical scavenging property of L. deliciosus has also been reported to be higher than the activity of most conventional antioxidants such as butylated hydroxytoluene and trolox [12]. Early research has shown that isolates from mushrooms have anticancer, cardiovascular, antiviral, antiparasitic, antibacterial, anti-inflammatory, blood lipid-lowering, immune response stimulating, and even antidiabetic effects [34-36]. Currently, extracts from several mushrooms including $L$. deliciosus have widespread application in Japan, Korea, and China, being used as potential adjuvants to radiation and chemotherapy $[10,13]$

\section{Antibacterial potential of $L$. deliciosus extracts}

The bioactive compounds (phenolic and flavonoids) of $L$. deliciosus have been extracted using different extracting medium and tested for activities against selected microorganisms for potential use as natural antimicrobial agents. Baros et al. studied the antimicrobial properties of phenolic extracts of Portuguese wild edible mushroom species (L. deliciosus, Sarcodon imbricatus, and Tricholoma portentosum) against microbial pathogens. In the report, it was demonstrated that L. deliciosus had the greater effect on all the tested microorganisms owing to its higher total phenolic content. The observed total phenolic, flavonoids and ascorbic acid contents of L. deliciosus extracts were $17.25 \pm 0.65,8.14 \pm 0.81$, and $0.24 \pm 0.02 \mathrm{mg} / \mathrm{g}$, respectively [12]. When the extracts were tested against Bacillus cereus, Bacillus subtilis, Escherichia coli, Pseudomonas aeruginosa, Candida albicans, and Cryptococcus neoformans, $L$. deliciosus extracts expressed a strong antibacterial inhibitory activity against all the species tested at a minimum inhibitory concentration (MIC) of $10 \mathrm{mg} / \mathrm{mL}$, except for E. coli, where even a higher of $300 \mathrm{mg} / \mathrm{mL}$ showed no inhibitory activity. E. coli expressed strong resistance to all the tested extracts from the three mushrooms tested, implying that the resistance to the extracts of $L$. deliciosus was not in isolation, but a general phenomenon likely due to gene variation [12].

Dilsad et al. studied the antimicrobial, antioxidant activities and chemical composition of $L$. deliciosus collected from Kastamonu Province of Turkey and reported that the highest inhibitory activity was found against $P$. aeruginosa with an inhibition zone of $30 \pm 00 \mathrm{~mm}$ using acetone and ethanol as extraction solvents. The study equally reported weak inhibitory action against $S$. aureus and $C$. albicans with a zone of inhibition measuring $<9 \mathrm{~mm}$ in diameter using dimethylsulfoxide and distilled water as extraction solvents [23]. The antibacterial activity of most bioactive compounds depends on the solvent used during extraction. Various reports of varying activities have been reported 
regarding the antibacterial activities of $L$. deliciosus extracts, which seem to be higher when extracted with methanol, as compared to other extraction solvents. Dulger et al. reported that methanol extracts of L. delicious have been found to be effective against Mycobacterium sp. and greater antimicrobial activity against Gram-positive and Gram-negative bacteria, with little or no effect against yeasts [37].

Among the Lactarius spp., various studies have shown a different pattern of antimicrobial sensitivity among the members of the group, especially against E. coli. Looking at the individual reports among the Lactarius spp., Ozen et al. reported that among Lactarius piperatus, Lactarius camphorates, Lactarius volemus, and L. delicious, L. camphorates showed more antibacterial activity against $E$. coli and other studied organisms [25], whereas Dulger et al. reported that $L$. deliciosus was more effective against $E$. coli than other members of the Lactarius family [37]. Barros et al. studied the effect of fruiting body maturity stage on the chemical composition and antimicrobial activity of Lactarius spp. mushrooms and reported that $L$. deliciosus had the highest antibacterial effect against $E$. coli among the six species studied [1].

\section{Antitumor potential of $\boldsymbol{L}$. deliciosus extracts}

Based on available literature, a few reports have been documented on the antitumor activities of whole extracts from L. deliciosus. However, there have been reports on the antioxidant and scavenging potentials of extracts from L. deliciosus. Having known the role of the total phenols and flavonoids in radical scavenging, more works on the antitumor potential of the extract from $L$. deliciosus becomes inevitable. Marijana et al. studied growth inhibitory effects of methanol extracts of L. deliciosus on human epithelial carcinoma (HeLa), human lung carcinoma (A549), and human colon carcinoma (LS174) cell lines and reported that the mushroom showed anticancer potential with an $\mathrm{IC}_{50}$ against tested cells ranging from $19.01 \mathrm{mg} / \mathrm{mL}$ to $80.27 \mathrm{mg} / \mathrm{mL}$. The $\mathrm{IC}_{50}$ for L. deliciosus against HeLa, A549, and LS174 cells lines was $19.01,33.05$, and $74.01 \mathrm{mg} / \mathrm{mL}$, respectively [27]. This is the only reported investigation into the anticancer potential of $L$. deliciosus crude extract against cell lines, thereby paving the way for the investigation of the antitumor activities against a broader range of cell lines.

Some works have also been reported on the activity of some polysaccharides extracted from this mushroom, having antitumor activities. Ding et al. reported a novel polysaccharide from $L$. deliciosus during the study of the structure, feature, and antitumor activity of a novel polysaccharide isolated from $L$. deliciosus gray. The polysaccharide codenamed LDG-A was used on mice S180 tumor to evaluate the antitumor effects of the polysaccharide [38]. From the results, LDG-A was found to be able to inhibit the growth of the tumors in a dosedependent fashion. The rate of inhibition in the mice treated with about $80 \mathrm{mg} / \mathrm{kg}$ LDG-A was found to be $68.422 \%$, which actually was the highest dose tested, thereby showing the greatest rate of inhibition. The antitumor activity of the isolated polysaccharide was believed to be a result of the activation of the cell-mediated immune response in the host [39]. A summary of the antitumor activity of the L. deliciosus polysaccharide isolated by Ding et al. is shown in Table 2.

From the results, Ding et al. observed that there was minimal change in the average liver weight of the test groups, which indicated that the LDG-A from L. deliciosus did not cause serious liver damage and could be a potential antitumor agent with a good chemotherapeutic index. The study concluded that the activation of the immune responses in the host might likely be one of the mechanisms of antitumor activity of LDG-A, which has been the case for many antitumor polysaccharides already in use.

\section{Antioxidant potential of $L$. deliciosus extracts}

The antioxidant potential of $L$. deliciosus has been investigated and reported by a number of authors. The most common method of investigating the antioxidant potential of the mushroom has been the scavenging of 1,1-diphenyl-2-picryl-hydrazil (DPPH). Marijana et al. reported that methanol extracts of L. deliciosus showed lower scavenging property when compared to the standard ascorbic acid which served as the control. The extracts of $L$. deliciosus had a DPPH radical scavenging $\left(\mathrm{IC}_{50}\right)$ of $493.82 \pm 2.35 \mu \mathrm{g} / \mathrm{mL}$, which was much lower than the $6.42 \pm 0.18 \mu \mathrm{g} / \mathrm{mL}$ of the ascorbic acid which served as the control [27]. Similarly, Ferreira et al. studied the free radical scavenging capacity and reducing power of wild edible mushrooms from Northeast Portugal and reported that the extracts of L. deliciosus had higher scavenging property on DPPH when compared to the scavenging power of T. portentosum. The L. deliciosus extract presented a scavenging ability of $79.1-84.3 \%$ at $50 \mathrm{mg} / \mathrm{mL}$ which was better than the $30.4-65.0 \%$ at $50 \mathrm{mg} / \mathrm{mL}$ of T. portentosum. Butylated hydroxyanisole (BHA) and $\alpha$-tocopherols were used as controls, presenting higher scavenging effects of $3.6 \mathrm{mg} / \mathrm{mL}$ for BHA and $8.6 \mathrm{mg} / \mathrm{mL}$ for $\alpha$-tocopherols being $96 \%$ and $95 \%$, respectively. They also reported that the extracts obtained from the cap of the mushroom scavenged DPPH radicals at a higher percentage that extracts from the other parts (body and rhizomes) of the mushroom [30].

Studying the antioxidant, antimicrobial activities and chemical composition of edible mushrooms grown wildly in the Black Sea Region of Turkey, Ozen et al. reported that all the tested mushrooms, including the extracts from L. deliciosus, showed moderate scavenging effects on DPPH. The level of scavenging effects was lower in some mushrooms studied compared to $\alpha$-tocopherols including L. deliciosus (51\%) than the scavenging effects of $\alpha$-tocopherols (60\%) which served as control. The scavenging effects of extracts from Ramaria flava (80\%), Macrolepiota procera (69\%), L. volemus (61\%), Lactarius camphoratus (61\%), and L. piperatus (61\%) were higher than the scavenging effects of $\alpha$-tocopherols (60\%) [25].

\section{COMATUS}

C. comatus or lawyer's wig is a macrofungus often seen growing along gravel roads and lawns. Sometimes, they are seen growing on dirty areas with the young fruiting bodies appearing first as white cylinders growing up from the ground, followed by the bell-shaped caps which open out later. When the caps opened, the gills under the cap are white, then changes to pink, and finally turns black before secreting a black liquid that is filled with the spores. This is the reason it is sometimes regarded as the "ink cap." Due to the short lifespan of this mushroom, it is unusual because as soon as it turns black, it auto dissolves in a matter of hours. Long-term storage of the mushroom can be achieved through drying, freezing, or microwaving [40]. Taxonomically, C. comatus is a species belonging to the genus Coprinus.

This genus Coprinus was originally considered as a large genus with over 100 species. However, on molecular analysis of DNA sequences, it showed that the former species belonged to two families, known as the Agaricaceae and the Psathyrellaceae. The species C. comatus is the best known of the member of the true Coprinus [41]. Descriptively, C. comatus is easily recognized by its cylindrical mostly whitish shaggy cap that initially covers most of the stem. The cap of the mushroom is usually paler and uses to change from white to pink rapidly before finally turning black. It absorbs water from the environment when exposed, conferring to it the deliquescent status. It has stipe which usually measures about $10-37 \mathrm{~cm}$ in height and about $1-2.5 \mathrm{~cm}$ in diameter. At the microscopic level, it does not possess pleurocystidia, and the spore print is usually blackish brown, with the spores measuring about 10-13 $\mu \mathrm{m}$. It has a whitish flesh and also tastes mild [41].

\section{Nutritional benefits of $C$. comatus}

C. comatus when young contains about $25 \%$ proteins and is also rich in triglycerides, mainly made up of linoleic acid. Traditionally, it is used in Chinese medicine for the treatment of piles and to improve digestion [42]. The consumption of $C$. comatus has been reported to cause recovery from alcoholic effects when tried in experimental animals [43]. The total energy derivable from $100 \mathrm{~g}$ of the mushroom is about $349 \mathrm{Kcal}$, meaning it is usually low in caloric content. The protein content is about $37 \%$, water content made up about $13.5 \%$, ash content 
Table 2: Anti-tumor activities of $L$. deliciosus (LDG-A) polysaccharide on S180 tumor

\begin{tabular}{llllll}
\hline Group & Spleen index $(\mathbf{m g} / \mathbf{g})$ & Liver index $(\mathbf{m g} / \mathbf{g})$ & Thymus index $\mathbf{( m g} / \mathbf{g})$ & Average tumor weight (g) & $\begin{array}{l}\text { Inhibitory rate of } \\
\text { tumor (\%) }\end{array}$ \\
\hline Negative control & $5.784 \pm 2.108$ & $60.307 \pm 9.395$ & $1.429 \pm 0.706$ & $3.740 \pm 0.423$ & - \\
$20 \mathrm{mg} / \mathrm{kg}$ & $7.619 \pm 2.414$ & $56.468 \pm 4.509$ & $4.741 \pm 0.301$ & $2.081 \pm 0.740$ & 44.358 \\
$40 \mathrm{mg} / \mathrm{kg}$ & $7.807 \pm 3.427$ & $66.351 \pm 8.802$ & $7.790 \pm 3.208$ & $1.783 \pm 0.430$ & 52.326 \\
$80 \mathrm{mg} / \mathrm{kg}$ & $5.202 \pm 0.989$ & $59.977 \pm 4.786$ & $0.903 \pm 0.401$ & $1.181 \pm 0.241$ & 64.422 \\
Positive control & $7.0439 \pm 3.105$ & $58.263 \pm 5.399$ & $2.862 \pm 1.727$ & $1.581 \pm 0.706$ & 57.727 \\
\hline
\end{tabular}

Adapted from [38]

accounted for about $5.5 \%$, while fats and oil and carbohydrates contents accounted for $5 \%$ and $39 \%$, respectively [43]. A profile of the fatty acid content of the extracts from $C$. comatus using GC-FID showed that it is majorly composed of linoleic acid (C18:2n6c) (66.6\%), palmitic acid (C16:0) (11.8\%), palmitoleic acid (C16:1) (5.4\%), stearic acid (C18:0) (3.3\%), oleic acid (C18:1n9c) (6.1\%), and linolenic acid (C18:3n3) (1.1\%). These are lipids that have been proven to be of beneficial use to the normal functioning of the brain and the nervous systems [44]. The vitamin content of $C$. comatus was also investigated and reported to contain the following vitamins at the following concentrations: Thiamin (vitamin B1) $(7.5 \mathrm{mg} / 100 \mathrm{~g})$, riboflavin (vitamin B2) $(0.45 \mathrm{mg} / 100 \mathrm{~g})$, retinol (vitamin A) $(<50 \mathrm{mg} / 100 \mathrm{~g})$, ascorbic acid (vitamin C) $(6.15 \mathrm{mg} / 100 \mathrm{~g}), \alpha$-tocopherols (vitamin E) $(<1 \mathrm{mg} / 100 \mathrm{~g})$, and niacin+niacinamide (vitamin $\left.B_{3}\right)(<1 \mathrm{mg} / 100 \mathrm{~g})$ [44]. These indicated that the mushroom is a good source of the important vitamins required for daily body function.

\section{Antibacterial potentials of $C$. comatus extracts}

The antibacterial activity of methanolic extracts both cultivated and wild $C$. comatus has been previously investigated by Dejan et al. and documented as follows: The samples from both cultivated and wild C. comatus showed strong antibacterial activity against all the bacteria that were tested. Wild and cultivated extracts of $C$. comatus exhibited the highest antibacterial activity against $S$. aureus (MIC of 0.0625 and $1.5 \mathrm{mg} / \mathrm{mL}$; minimum bactericidal concentration $[\mathrm{MBC}]$ of 0.125 and $3.0 \mathrm{mg} / \mathrm{mL}$ ) and B. cereus (MIC of 0.0625 and $0.75 \mathrm{mg} / \mathrm{mL}$; MBC of 0.125 and $3.0 \mathrm{mg} / \mathrm{mL}$ ). The lowest observed antibacterial activity was achieved recorded against E. coli with MIC of $3.0 \mathrm{mg} / \mathrm{mL}$ and MBC of $6.0 \mathrm{mg} / \mathrm{mL}$. The methanolic extract of the cultivated C. comatus extract was reported with higher antibacterial potential in general, as compared to the extracts from the wild sample. This could be attributed to the controlled environment, in which the cultivated mushroom was grown. It was also reported that against E. coli, both extracts exhibited the same level of activities [45]. A summary of the activities of the wild and cultivated extracts of $C$. comatus as was documented by Mull et al. is presented in Table 3 .

Similarly, Ehssan et al. studied antibacterial activity of wild mushrooms from the Khartoum state of Sudan and reported that the ethanol extract of $C$. comatus was very active against almost all of the tested organisms, except for Aspergillus niger where it showed some resistance. It was also reported that the petroleum extracts from the mushroom were not active against all the tested organisms [46]. These activities were concluded to be due to the presence of bioactive compounds such as alkaloids, flavonoids, phenolic, saponins, sterols, carbohydrates, tannins, coumarins, and cyanogenic glycosides, as well as the solubility of these compounds in the extraction solvent.

Kalaw and Albinto studied the functional activities of Philippine wild strain of C. comatus and Pleurotus cystidiosus grown on rice straw and noted that ethanol and acetone extracts of the mushrooms were able to inhibit the growth of $S$. aureus though $C$. comatus ethanol extract showed a wider zone of inhibition, recording a mean inhibition diameter of $14.09 \mathrm{~mm}$, as compared to acetone extract, with a mean inhibition diameter of $13.43 \mathrm{~mm}$. However, on the other hand, it was reported that $P$. cystidiosus acetone extract showed a larger inhibition zone with a mean diameter of $15.25 \mathrm{~mm}$ than that of ethanol extract which has a mean diameter of $13.16 \mathrm{~mm}$. No activity was recorded against $E$. coli when the ethanol and acetone extracts of both mushroom species were tested against the bacteria. This showed that both mushrooms can exhibit potential antibacterial activities, but the extent of activity depends on the solvent used during the extraction process [47]. Furthermore, Srivastava and Sharma showed that the antimicrobial activity of mushroom depends on the solvent used for extraction as well as the strain of the fungus. Similarly, Iwalokun et al. demonstrated that petroleum ether and acetone extracts of P. ostreatus inhibited the growth of both Gram-positive and Gram-negative bacteria, as well as fungi, tested $[35,48]$.

\section{Antitumor potential of $C$. comatus extracts}

Studies on the antitumor potential of extracts from $C$. comatus against selected cell lines have been investigated and reported previously, with recommendations for further studies on other range of human cancer cell lines. Few of the works already reported showed that the mushroom has antitumor potential against tested cell lines due to the abundance of phenolic and flavonoids in the mushroom. Zaidman et al. studied the effects of $C$. comatus and G. lucidum interference with androgen receptor function in LNCaP prostate cancer cells and reported that the extracts of both mushrooms inhibited the proliferation of the prostate cancer LNCaP cells with $\mathrm{IC}_{50}$ values of $28.3 \mathrm{~g} / \mathrm{mL}$ for $C$. comatus and $44.8 \mathrm{l} \mathrm{g} / \mathrm{mL}$ for G. lucidum. However, interestingly, they also reported that a significantly higher concentration of the C. comatus extract was needed to cause $50 \%$ growth inhibition of the other tested cell lines, meaning that the $C$. comatus extract had an appreciable level of selectivity toward LNCaP cell lines, as compared to the extracts of G. lucidum which showed lesser selectivity [42]. The study also showed that the extracts of $C$. comatus were able to selectively affect the cell cycle progression of prostate cancer PCa cell lines, comprised LNCaP, PC-3, and DU 145 .

Small and Roach studied the effects of $C$. comatus and G. lucidum extracts on the level of secreted prostate-specific antigen (PSA) from LNCaP cell line in a dose-dependent manner study and found that the extracts successfully decreased the level of PSA secreted while treatment with dihydrotestosterone (DHT) caused an increase in the level of secreted PSA by 2.47 -fold [49]. Zaidman et al. in a similar manner also studied the effect of DHT treatment of LNCaP cells (PSA release) and compared it with the treatment of $C$. comatus extract. The results showed that the treatment with DHT caused an appreciable increase in the level of PSA whereas treatment with flutamide caused a moderate reduction in the PSA production level. However, with the $C$. comatus extract treatment, a significant decrease in the level of PSA levels in a dose-dependent manner [42].

In another study, Rouhana-Toubi et al. studied the effect of dry powder of C. comatus fruiting bodies extracted using ethyl acetate on the viability of three cell lines from human ovarian cancer (ES-2, SKOV-3, and SW-626). In the conclusion of the study, they reported that the mushroom extract was very active against all the tested cell lines, in a dose-dependent manner. However, to know which fraction of the crude extract was more active against the cells, the crude extract was subjected to purification using chromatography on a silica gel column. At the end of the purification and further testing of the resulting six different fractions on the cells, they observed more significantly effective action with the last elute than the crude extract in the reduction of cell viability. To cap it all, the study summarized that the 
Table 3: Antibacterial activity of the methanolic extracts and standard drugs (mean \pm SD)

\begin{tabular}{|c|c|c|c|c|}
\hline Bacteria & $\begin{array}{l}\text { Coprinus comatus (cultivated) } \\
(\mathrm{mg} / \mathrm{mL})\end{array}$ & $\begin{array}{l}\text { Coprinus comatus (wild) } \\
(\mathrm{mg} / \mathrm{mL})\end{array}$ & Ampicillin (mg/mL) & Streptomycin $(\mathrm{mg} / \mathrm{mL})$ \\
\hline \multicolumn{5}{|c|}{ Staphylococcus aureus } \\
\hline MIC & $0.0625 \pm 0.00$ & $1.5 \pm 0.10$ & $0.25 \pm 0.05$ & $0.04 \pm 0.00$ \\
\hline MBC & $0.125 \pm 0.00$ & $3.0 \pm 0.30$ & $0.37 \pm 0.02$ & $0.09 \pm 0.00$ \\
\hline \multicolumn{5}{|c|}{ Bacillus cereus } \\
\hline MIC & $0.0625 \pm 0.00$ & $0.75 \pm 0.00$ & $0.25 \pm 0.00$ & $0.09 \pm 0.00$ \\
\hline MBC & $0.125 \pm 0.01$ & $3.0 \pm 0.10$ & $0.37 \pm 0.02$ & $0.17 \pm 0.01$ \\
\hline \multicolumn{5}{|c|}{ Myotis flavus } \\
\hline MIC & $1.5 \pm 0.10$ & $1.5 \pm 0.30$ & $0.25 \pm 0.03$ & $0.17 \pm 0.02$ \\
\hline MBC & $3.0 \pm 0.30$ & $6.25 \pm 0.30$ & $0.37 \pm 0.00$ & $0.34 \pm 0.02$ \\
\hline \multicolumn{5}{|c|}{ Listeria monocytogenes } \\
\hline MIC & $0.75 \pm 0.10$ & $3.0 \pm 0.10$ & $0.37 \pm 0.01$ & $0.17 \pm 0.01$ \\
\hline MBC & $3.0 \pm 0.00$ & $6.25 \pm 0.30$ & $0.49 \pm 0.03$ & $0.34 \pm 0.00$ \\
\hline \multicolumn{5}{|c|}{ Pseudomonas aeruginosa } \\
\hline MIC & $0.35 \pm 0.03$ & $1.5 \pm 0.30$ & $0.74 \pm 0.02$ & $0.17 \pm 0.04$ \\
\hline MBC & $3.0 \pm 0.10$ & $3.0 \pm 0.30$ & $1.24 \pm 0.00$ & $0.34 \pm 0.03$ \\
\hline \multicolumn{5}{|c|}{ Salmonella typhimurium } \\
\hline MIC & $3.0 \pm 0.30$ & $1.5 \pm 0.00$ & $0.37 \pm 0.01$ & $0.17 \pm 0.00$ \\
\hline MBC & $6.25 \pm 0.10$ & $3.0 \pm 0.00$ & $0.49 \pm 0.03$ & $0.34 \pm 0.01$ \\
\hline \multicolumn{5}{|c|}{ Escherichia coli } \\
\hline MIC & $3.0 \pm 0.10$ & $3.0 \pm 0.10$ & $0.25 \pm 0.05$ & $0.17 \pm 0.03$ \\
\hline MBC & $6.25 \pm 0.01$ & $6.25 \pm 0.30$ & $0.49 \pm 0.05$ & $0.34 \pm 0.02$ \\
\hline \multicolumn{5}{|c|}{ Enterobacter cloacae } \\
\hline MIC & $3.0 \pm 0.10$ & $1.5 \pm 0.10$ & $0.37 \pm 0.05$ & $0.26 \pm 0.01$ \\
\hline MBC & $6.25 \pm 0.10$ & $6.25 \pm 0.00$ & $0.74 \pm 0.07$ & $0.52 \pm 0.02$ \\
\hline
\end{tabular}

Adapted from [45]. SD: Standard deviation, MIC: Minimum inhibitory concentration, MBC: Minimum bactericidal concentration

ethyl acetate extract of $C$. comatus reduced the viability of the three cell lines of human ovarian cancer [50]. These reports from previous studies suggest that the tendency of producing antitumor drugs from natural sources, especially from mushrooms, is realizable.

Further studies on the ways to promote the delivery of the drugs to the target cells and the possibility of a synergy in the action of the compounds with other compounds or materials of pharmacological interests deserve investigation for enhanced activities. The potential of nanoparticles serving as therapeutic and delivery agents has been investigated, and various reports suggested that nanoparticles can be applied directly as a therapeutic agent against human cancer proliferation as well as a dependable delivery agent of bioactive compounds [8,51]. On this note, a mini review of some of the nanoparticles of pharmacological importance is been carried out, with a view of finding out the particular properties and characteristics that confer the status of a pharmacological important particle. Furthermore, a review of the possible ways to encapsulate the bioactive compounds extracted from the studied mushrooms on the nanoparticle of interest for better performance of the bioactive compound nanoparticle complex against selected human cell lines and microorganisms.

\section{THE ERA OF NANOTECHNOLOGY IN PHARMACEUTICAL SCIENCES}

Nanotechnology was introduced into pharmaceutical sciences in the $19^{\text {th }}$ century when Paul Ehrlich during his study described it a magic bullet, which was employed to specifically deliver the drug of interest to the target cell without much effect to the host system. This necessitated further studies into the transition of particle size from microscale to nanoscale [52]. Drug targeting attracted interest in the recent years due to the fact that drugs possess both positive and negative effects on the host cells. The requirement/properties of ideal drug delivery system include being able to be extended into the blood circulation and must be targeted against a selected disease targets. Furthermore, it must be able to accurately deliver the drug of interest and has also been able to be excreted from the body through normal metabolic pathways. Hence, many materials have presently been studied for application as drug delivery systems with different manufacturing methods and modifications being established, while others are investigated for potential activities against target cells [52].
During the early days of nanoparticles development, they were initially used as carriers for the delivery of vaccines and anticancer drugs for improved uptake. Furthermore, studies were carried out on ways to reduce the intake of the nanoparticles by the cells of the reticuloendothelial system [53]. Nanoparticles for pharmaceutical use have to do with evolving technologies as a way of addressing emerging diseases and improvement of the drug delivery systems. Drug delivery systems ought to have an impact on the rate of absorption, metabolism, distribution, as well as excretion of the drug metabolites in a positive way. Similarly, drug delivery systems ought to permit the drugs to actively bind to their target cells and enhance receptor's signaling and response [53].

\section{Nanoparticles as drug delivery agents}

\section{Peptides and proteins delivery}

The increase in the number of biotechnological molecules such as monoclonal antibodies, vaccines, and hormone, as well as their pharmaceutical potentials, makes it interesting for studies into the protein delivery system [54]. In the structure of proteins, stability is mainly a result of the balance between stabilizing and destabilizing forces exerting effects on the secondary, tertiary, and quaternary structures of the protein. The formation and maintenance of the stability of these structures are based on weak interactions such as electrostatic interactions, van der Waals force, and hydrogen bonding which hold these structures together. Alteration of any of these weak forces shifts the delicate balance of these protein structures and destabilizes the proteins [54]. The physical and chemical stability of these proteins can be altered by external factors such as $\mathrm{pH}$, temperature, $\mathrm{pH}$, ionic strength, high pressure, metal ions, non-aqueous solvents, adsorption, detergents, and agitation.

Solid lipid particulate systems such as solid lipid nanoparticles (LNs), lipospheres, and lipid microparticles have been used as an alternative delivery system for therapeutic peptides, antigens, and proteins, and research in this regard confirms that under optimized conditions, these particulate systems could be produced to incorporate hydrophilic or hydrophobic proteins and could serve as a particulate carrier system. Proteins and antigens meant for pharmaceutical purposes may be encapsulated or adsorbed onto the particulate system and administered by various routes such as through parenteral, oral, 
nasal, or pulmonary routes. The encapsulation of the proteins in the particulate system adds to the stability of the protein, avoids proteolytic degradation, and also ensures a sustained release of the incorporated material [51]. In application, lipid particulate systems have been used as a delivery system of drugs where higher amounts of the drug were found in the brain after intravenous injection, suggesting the potential use of the particulate system in delivering drugs to the brain without crossing the blood-brain barrier [55].

\section{Antitumor drugs delivery}

Some of the characteristics which prompted the use of nanoparticles for the delivery of antitumor drugs include the following: (a) delivery of reasonable amount of drug within the surrounding of the target tumor through the enhanced retention and permeability or ligands active targeting on the surface of the nanoparticles and (b) reduction of the exposure of healthy cells and tissues to the drugs through the limitation of drug distribution to only target tissues and organs. Researchers have demonstrated that the hydrophobicity, biodegradation profile, drugs molecular weight, localization in the nanosphere, mode of incorporation and absorption have an influence on how drugs attached to nanoparticles are distributed inside the body. Although the major mechanism is yet to be fully understood, the biodistribution of nanoparticles is fast and could be completed within 60-180 minutes, prompting that the activity of the mononuclear phagocytic system (MPS) and the endocytosis/phagocytosis process might be involved. Such propensity of nanoparticles biodistribution gives the opportunity to efficiently deliver drugs to the target cells without adverse effect to the surrounding healthy cells and tissues. The effectiveness of the biodistribution of drugs through the nanopathway could be of importance in the chemotherapeutic treatment of organs laden with MPS-localized tumors such as hepatocarcinoma and hepatic metastasis hepatic metastasis originating from digestive tract, bronchopulmonary tumors, gynecological cancers, primitive tumors and metastasis, myeloma, small cell tumors, and leukemia [56,57].

\section{Dermatology drug delivery}

In the field of nanotechnology, manufacturing of elaborate nanosized particles for several applications has been allowed in recent times. Some of the new applications of this technology include the controlled release of drugs to skin and its appendages, transcutaneous vaccination, hair follicle (HF) targeting, and transdermal gene therapy. The delivery systems of this new generation carrier take the advantages of an enhanced skin penetration potentials, surface functionalization, and depot effect with sustained drug release, thereby allowing targeting of specific cells. The treatment of various types of skin diseases could be revolutionized through the use of nanomaterials as the delivery systems [57].

Of particular interest in the field of dermal drug delivery through the nanopathway is delivery with LN. This has been demonstrated to be effective for the treatment of the diseases of the HF, for an increased local bioavailability of active pharmaceutical ingredient (API) at their drug target. Nelson et al. identified that isotretinoin can cause the arrest of a cell cycle as well as apoptosis in sebocytes [58], whereas Messenger and Rundegren reported that minoxidil activated the synthesis of the vascular endothelial growth factor and prostaglandin in the dermal papilla [59], cyclosporine A was also reported by Takahashi and Kamimura to support the growth of hair epithelial cell growth [60]. In dermal therapy, the major objective is to reduce the systemic side effects of drugs through local administration of the API. The idea of using nanotechnology for the delivery of these drugs is already making gains and further development guarantees effective drug delivery to target cells without adverse effects on the surrounding healthy cells.

\section{In cosmetics}

Studies have shown promising areas of nanoparticles been used in several cosmetic products such as deodorant, toothpaste, soaps, shampoo, anti-wrinkles, hair conditioners, moisturizing creams, foundation, lipsticks, face powder, eye shadows, nail polishes, and perfumes. Nanoparticles (nanostructured lipid carriers) have been shown as a potential next-generation cosmetic delivery agent capable of providing improved skin hydration, stability of the agent, bioavailability, and controlled occlusion [61]

Other applications of nanotechnology in cosmetics are as follows: a. Sunscreens

Gibson et al. studied advances in diffuse optical imaging with emphasis on ultraviolet (UV) filters and concluded that filters such as titanium dioxide $\left(\mathrm{TiO}_{2}\right)$ and zinc oxide can be used in the nanoscale instead of higher forms to make sunscreens more transparent instead of being white [62].

b. Breast cream

In the formulation of its breast cream using herbal products, St Herb Nano Breast Cream claims to have used a combination of nanomaterial and Pueraria mirifica, a Thai herbal plant during the production of the cream [63].

c. Hair care

In hair care, the RBC Life Sciences Nanoceuticals have used nanoclusters in the formulation of its citrus mint shampoo and conditioners, which confer hair with a healthy shining look $[64,65]$.

d. Make-up

The use of nanodispersion technology has aided Serge Lutens Blusher to produce an extremely fine and light powder which possesses extraordinary properties with excellent elasticity, light diffusion, and extreme softness [65].

e. Moisturizers/anti-wrinkles

The application of nanotechnology in cosmetics has helped in the manufacture of various moisturizing creams and anti-wrinkles. Lancôme encapsulated triceramide in its Hydra Zen Cream to renew the healthy look of the skin healthy, while L'Oreal Revitalift Double Lifting anti-wrinkle cream contains nanosomes of proretinol A [65].

This is evidence of the application of nanotechnology not only in the treatment of diseases but also in the production of life-aiding products.

\section{NANOPARTICLES WITH PHARMACOLOGICAL POTENTIALS}

Various studies have been carried out on the pharmacopotential of various materials when used as nanoparticles. Most of the nanomaterials (sized $>100 \mu \mathrm{m}$ ) when reduced to the nanoparticles $(<100 \mu \mathrm{m})$ exhibited pharmacological properties which when tested against various cell lines and were able to inhibit or reduce the growth of major human cancer cell lines. The materials investigated showed antitumor, antioxidant, as well as antibacterial potentials. A mini review of some nanoparticles and their recent application for pharmacological benefits was carried out here with the intent of identifying the pharmacodynamics surrounding their application. This review should not be seen as an exhaustive review of all the nanomaterials of pharmacological potential because there are so many reviews and works covering various aspects of this topic.

\section{Cerium oxide nanoparticles}

Cerium oxide is an oxide of the rare earth metal cerium, which is a pale yellow to white powder with the chemical formula $\mathrm{CeO}_{2}$. Cerium oxide is an important product commercially and exists as an intermediate during the purification of the element from the ores. The cerium (IV) oxide is formed through the calcination of cerium oxalate or cerium hydroxide at a high temperature. The mechanism of action and biological properties of cerium oxide is well understood owing to the fact that its ions switch between two valence state $\left(\mathrm{Ce}^{3+}\right.$ and $\left.\mathrm{Ce}^{4+}\right)$. This two-valence state exists on the surface of the cerium oxide when it is synthesized as a nanoparticle. This deficiency in charge resulting from $\mathrm{Ce}^{3+}$ is rightly compensated through the formation of oxygen vacancies, which confer to cerium nanoparticles (CNPs), an intrinsic antioxidant property [66-68] 


\section{Mechanism of action}

The mechanism of action of CNPs shares similarities with most naturally-occurring metalloenzymes, which utilizes the transition metals cofactors such as $\mathrm{Fe}, \mathrm{Cu}, \mathrm{Zn}$, or Mn to scavenge ROS in cells. CNPs have been shown to mimic the enzyme superoxide dismutase (SOD), when the $\mathrm{Ce}^{3+}$ form of it reacts with superoxide, thereby changing to $\mathrm{Ce}^{4+}$ while simultaneously reducing the superoxide into hydrogen peroxide $[27,69]$. Similarly, the oxidation of $\mathrm{Ce}^{3+}$ to $\mathrm{Ce}^{4+}$ ions permits the scavenging of other reactive species such as hydroxyl radicals [70], NO [71], and peroxynitrite (ONOO) [68]. Consequently, $\mathrm{Ce}^{4+}$ can be reduced to $\mathrm{Ce}^{3+}$ during the oxidation of $\mathrm{H}_{2} \mathrm{O}_{2}$ to $\mathrm{O}_{2}$, just in the same manner as catalase enzyme [72]. Therefore, the synergistic pair of $\mathrm{Ce}^{3+}$ and $\mathrm{Ce}^{4+}$ can alternately and reversibly switch forth and back even while scavenging peroxides and superoxide $[66,68,73]$.

When considering the catalase potentials and the SOD activities of CNPs together, it has been suggested that CNPs undergo a complete redox cycle during the scavenging of two superoxides and a hydrogen peroxide molecule [66], which will be a perfect way to limit/eliminate, in a sequential set of energy-free reactions, both superoxide and hydrogen peroxide [67], resulting in the freeing of the cells from the most abundant ROS. This ability of CNPs to self-regenerate antioxidants is a potential pharmacological tool, which will portray CNPs as a unique and attractive biological scavenger.

\section{Recent application in pharmacological studies}

During the study of the ability of cerium oxide nanoparticles to stimulate the proliferation of primary mouse embryonic fibroblasts in vitro, Popov et al. demonstrated that citrate-stabilized cerium oxide nanoparticles promoted the proliferative activity of primary mouse embryonic fibroblasts in vitro. They postulated that cerium oxide nanoparticles stimulated the proliferation of a cell in a wide range of concentrations, ranging from $10^{-3} \mathrm{M}$ to ${ }^{10-9} \mathrm{M}$, through the reduction of intracellular levels of ROS at the lag phase of the cell growth. Finally, they concluded that nanocrystalline ceria could be considered as a basis for the effective and affordable source of supplements during cell culturing [74].

Furthermore, several studies have been conducted with regard to neuropathies, often associated with oxidative conditions. In this regard, CNP pharmacologic potentials were tested on several neuronal models, both with and without the introduction of external oxidative stress sources. Treatment with CNPs was found not to have affected the viability of neurons, rather there was an increment in the life span of the neuron of cells isolated from the spinal cord of the rat [75], as well as protecting the neurons from mechanically induced trauma [76]. Accordingly, the brain lesions caused by oxidative stress in the cases of stroke-induced hypoxia and cerebral ischemia were reduced by CNPs [77]. CNPs have also been tried for the treatment of Alzheimer's disease, which is an oxidation related neurodegenerative disease, occasioned by the formation of beta-amyloid plaques [77]. Study on CNPs loaded with antibodies against beta-amyloids was tested in different cellular models, and the results show that the CNPs actually allowed the preservation of the normal neural cells morphology, while significantly inhibiting neuron agglomeration and apoptosis $[78,79]$.

\section{Platinum nanoparticles (PNPs)}

The catalytic properties of the inert noble gasses such as palladium, gold, and platinum, when reduced to the nanoscale, are gaining mush research interest for potential application as pharmacological agents [80-82]. PNPs are considered promising materials for the treatment of conditions related to oxidative stress due to their potent antioxidant potential and experiments conducted by Hamasaki et al., and Kajita et al. have shown that PNPs can actually interact or react with various ROS such as superoxides and hydrogen peroxide in oxidativerelated diseases $[83,84]$. PNPs also possess SOD activity in a similar way as the CNPs which made them an interesting biological agent [85]. Irrespective of these interesting potentials and abilities of PNPs, Caputo et al. stated that the basic mechanism of action of the nanoplatinum and its catalase-like activity still remains to be either investigated or even postulated [86].

\section{Recent application}

Hamasaki et al. [83] investigated the use of PNPs in the scavenging of UV-induced ROS in HeLa cells and found that they were able to preserve the viability of the cells [83], while Onizawa et al. noted that the PNPs were able to shield experimental mice exposed to extracts from cigarette smoke extract, thereby reducing the development of neutrophilic inflammation in the lungs of the mice [87]. Furthermore, owing to their anti-inflammatory properties, the PNPs were found by Kim et al. to modulate the activation of the redox-sensitive NF-kappa B, as well as displaying interesting antiaging properties which are associated with its SOD and catalase-like activities and significantly extending the lifespan of Caenorhabditis elegans [88,89].

\section{PNPs verses CNPs}

Not long ago, Clark et al. compared the antioxidant properties of PNPs and cerium oxide nanoparticles, employing similar quantities of CNPs and PNPs with an average diameter of 16 and $1.9 \mathrm{~nm}$, respectively. The study found that at an equal doses of $48 \mathrm{mg} / \mathrm{mL}$, the CNPs were able to show higher in vitro SOD activity when compared to the PNPs which showed a lower SOD activity and also that the CNPs were more effective than platinum NPs in the protection of the human breast fibrosarcoma cells from cell death induced by the activities of hydrogen peroxide [90].

\section{Zirconia nanoparticles}

Research in the area of the behavior of acids has found that just the strength of an acid does not matter during selection but the type of acidity possessed (Brønsted or Lewis) which actually matters for an improved acidity and selectivity. Brown and Hargreaves in 1999 noted that the introduction of super acidity on acids improves its activity and increases its selectivity [91]. The successful inclusion of the sulfate group on the zirconia skeleton has improved its application which has projected sulfated zirconia as a potential particle of great importance in many reactions, which tends to be improved when the size of the sulfated zirconia is reduced to nanosize [92,93]. The antioxidant, antibacterial, and antitumor potentials of sulfated zirconia have been investigated and reported recently [8], which opened the way for more studies on the other applications of the sulfated zirconia in nanosize for pharmacological benefits.

\section{Recent application}

The cytotoxicity potential of sulfated zirconia nanoparticles was investigated recently by Mftah et al. on human breast cancer (MCF-7), human liver cancer (HepG2), human colon cancer (HT29), and normal human breast (MCF-10a) cells. The investigation using sulfated zirconia nanoparticles showed that the particles have significant cytotoxic effects against the HT29 cells at almost every tested concentration, while investigations with the MCF-7 and HepG-2 cells showed that at a concentration of $15.6 \mu \mathrm{g} / \mathrm{mL}$, the particles had no significant adverse effect on the growth of the cells, while inhibiting the growth of all cell lines [8]. The study also reported that the $\mathrm{IC}_{50}$ values of sulfated zirconia nanoparticles against tested cell lines showed that the nanoparticles were more active against the HT-29 cells with an IC $_{50}$ value of $26.4 \mu \mathrm{g} / \mathrm{mL}$, while the HepG-2 and MCF-7 cells showed $\mathrm{IC}_{50}$ values of 61.8 and $81.8 \mu \mathrm{g} / \mathrm{mL}$, respectively. The normal cells MCF-10a cells which were also tested as controls showed the least sensitivity to the sulfated zirconia nanoparticles, having an $\mathrm{IC}_{50}$ value of $151.63 \mu \mathrm{g} / \mathrm{mL}$, compared to the breast cancer MCF-7 cells which were more sensitive, with a reported $\mathrm{IC}_{50}$ value of $89.9 \mu \mathrm{g} / \mathrm{mL}$ [8]. This is evidence of the antitumor potential of sulfated zirconia nanoparticle, demonstrating high sensitivity against tumor cells while at the same time showing lesser side effects to the normal cells.

The antimicrobial potential of sulfated zirconia was also tested against a range of microorganisms which are responsible for various human diseases. It was reported by Mftah et al. that the sulfated zirconia 
nanoparticles presented powerful antimicrobial activity against Gram-negative and Gram-positive bacteria tested. P. aeruginosa and methicillin-resistant $S$. aureus (MRSA) were reported as the most sensitive organisms, followed by Salmonella choleraesuis and B. subtilis. Against the fungal elements tested (C. albicans), antifungal activity was not detected, showing that the organisms were resistant to the activities of the particles [8]. Following the reported activity of sulfated zirconia nanoparticles against the selected microorganisms and tumor cells, it stands to reason that sulfated zirconia has a potential application in the field of pharmacological studies for further investigation, understanding, and utilization of its pharmacological attributed for human benefits.

\section{THE INTERACTION BETWEEN NANOMATERIALS AND THE HUMAN IMMUNE SYSTEM (NANOTOXICOLOGY)}

To defend the body against a host of invaders, the immune system employs various mechanisms such as complex detection, communication, and execution systems to protect and defend the organism from diseases. The two most recognized immune systems are the innate and the adaptive immune systems, both working in a specialized and functionalized pattern to ward off infection [34]. Evidence of a cross-link between the specialized cells of the two immune systems exists, such as the neutrophils which are innate cells but also involved in the workings of the adaptive immune system [35]. Farrera and Fadeel had proposed, during the study of the relationship between the immune system and engineered nanomaterials, that most, if not all, of the adverse effects of engineered nanomaterials are exerted through direct effects on the cells of the innate system. The cells implicated here were listed as the dendritic cells (DCs), the macrophages, the phagocytes, and the antigen-presenting cells [94]. A brief review of the interaction of nanomaterials with the two recognized human immune systems is carried out here for a better understanding of the interaction because it takes two to tango [94].

\section{Nanomaterials interaction with the innate immune system}

Phagocytosis is the major process through which the innate immune system recognizes process and responds to invading allergens. The understanding of the major processes involved in the interaction of phagocytosis with nanomaterials as well as the different population of cells which made up the cell populations and how they are activated is essential. Macrophages, when activated, can be divided into classically activated macrophages M1 or alternatively activated macrophages M2 [95]. M1 macrophages are more pro-inflammatory and leaned toward the killing of pathogens, while M2 macrophages are responsible for anti-inflammatory, tissue repair, and wound healing. The presence of Th1 cytokines has the ability to polarize macrophages toward the M1 phenotype, and the Th2 immune responses can induce macrophage polarization toward the M2 phenotype. Recently, studies by Jones et al. demonstrated that experimental mouse that is prone to Th1 immune response cleared introduced nanoparticles at a slower rate than rats prone to Th2 [96]. In the human sense of application, the study showed that the nature or status of the human immune system can determine how the body can clear nanoparticles when introduced into the body [94].

Nanoparticles have been reported to cause undesired effect, mainly caused by the impairment of phagocytic activities. The nanoparticle, SWCNTs, for instance, has been investigated by Witasp et al. and found to cause impairment in the ability of macrophages to engulf dead cell targets [97]. Similarly, ultrafine carbon particles have been shown to impede the ingestion microorganisms by the macrophages of human alveolar [98]. The exposure of macrophages to nanoparticles has been shown to cause an impaired ability of the activated macrophages to transition from M1- to M2-like state which was associated with a reduced phagocytic activity of the macrophages toward some bacteria. It was however concluded that the biological effects of nanoparticles may be indirectly manifested solely after challenging the normal cell function, such as clearance of bacteria [99].
Nanomaterials interaction with the adaptive immune system

A basic knowledge of the composition of the adaptive system and how it works will help in the understanding of how it interacts with foreign bodies for either recognition or elimination. The major function of the adaptive immune system is to proffer antibody-mediated immunity against foreign bodies. It is constituted primarily with the Bursa of Fabricius (B) cells and the thymus-derived (T) cells. These cells are further specialized with the B-cells being responsible for antibodymediated (humoral) immunity while the T-cells are more involved in the direct engagement (cell-mediated) with foreign bodies. The T-cells are further functionalized according to the nature of their role in body defense. The T-helper cells also called the $\mathrm{CD} 4^{+}$are involved in boosting antibodies production from the B-cells, while the T-helper cells are further classified into Th1, Th2, and Th17 depending on their cytokine profiles and role. Cytotoxic T-cells or $\mathrm{CD}^{+}$is involved in the direct killing of viral-infected and malignant cells, but the maintenance of the immune regulatory function is done by the regulatory T-cells (the "self" and "non-self" recognition process). The DCs form the link between the innate and the adaptive immune system, which are effective phagocytic cells that can as well possess the capacity to process and present an antigen for recognition [100].

The targeting of the DCs may have advantages and disadvantages as well. Rightful targeting of the DCs might be beneficial in the area of vaccination, whereas an undesired targeting of DCs might lead to toxicity, which might even include nanomaterial toxicity. Studies have shown that nanoparticles may alter the role of DCs and consequently affect B- and/or T-cells. For instance, multi-walled carbon nanotubes (MWCNTs) have been reported by Laverny et al. to alter the ability of the human monocytes to differentiate into DCs [101]. In addition, Tkach et al. demonstrated that the pulmonary exposure of mice to SWCNTs induced reduced proliferation of T-cells of the spleen although the direct effects the nanotubes had on the DCs [102].

The introduction of nanomaterials can either stimulate or suppress the function of the immune system as demonstrated by Mitchell et al., who found out through their investigation with animal models that the inhalation of MWCNTs caused a systemic suppression of the mice immune system, causing a decreased T-cell proliferation rate in the spleen, believed to be caused by a signal from the spleen, most likely the transforming growth factor-beta secreted by alveolar macrophages. As already mentioned, nanoparticles have been shown to influence T-cell proliferation, typically through an effect on antigen-presenting cells, leading to an enhanced T-cell stimulatory capacity [103-107].

To show the effect or tolerance of nanoparticles in human models, Schanen et al. demonstrated that when human was exposed to $\mathrm{TiO}_{2}$ it caused an elevated level of inflammatory cytokines, with an increased maturation of the DCs. In addition, the material $\left(\mathrm{TiO}_{2}\right)$ when in nanosize effectively primed the activation and proliferation of the native $\mathrm{CD}^{+}$ T-cells, which were more effective than the same material when applied in the micrometer size [108]. All foreign materials introduced into the body elicit a kind of immune reaction and the outcome of such reaction determines how beneficial or harmful the material could be. Nanoparticles with more benefits are currently considered for pharmacological benefits considering the potential gains which outweigh the hazards.

\section{THE PROPOSED SYNERGISTIC COMBINATION}

A beneficial synergistic antitumor and antibacterial activities against bacterial and tumor cells could be the possible outcome of a combination/encapsulation of bioactive extracts from mushrooms onto the nanoparticles. The encapsulation process could be done either during the synthesis of the nanoparticle through incorporation into the nanoparticle skeleton or after the synthesis through the addition of a carrier on the surface of the nanoparticle. This is the basis for this review to serve as an eye opener on the possibility of achieving a greater pharmacological activity through the encapsulation of bioactive compounds on nanoparticles for an enhanced activity. 


\section{CONCLUSION}

Nanomaterials possess both intrinsic and acquired identities, while the immune system is made up of the innate and adaptive systems, and it could be simply presumed that the interactions between nanomaterials and the immune system could be reciprocal in the sense that when the body is exposed to the nanomaterial, it may facilitate inflammation which involves the innate immune cells, which may also in some cases, digest the nanomaterials, leading to the reduction of its toxicity [109]. Encapsulation of the bioactive extracts from mushrooms onto the nanoparticle structure could proffer a synergistic pharmacological activity against targeted bacterial and tumor cells.

\section{REFERENCES}

1. Barros L, Cruz T, Baptista P, Estevinho LM, Ferreira IC. Wild and commercial mushrooms as source of nutrients and nutraceuticals. Food Chem Toxicol 2008;46(8):2742-7.

2. Gursoy N, Sarikurkcu C, Solak MH, Tepe B. Evaluation of antioxidant activities of 3 edible mushrooms: Ramaria flava (Schaef.: Fr.) Quél., Rhizopogon roseolus (Corda) T.M. Fries., and Russula delica Fr. Food Sci Biotchnol 2010;19(3):691-6.

3. Lam YW, Ng TB, Wang HX. Antiproliferative and antimitogenic activities in a peptide from puffball mushroom Calvatia caelata. Biochem Biophys Res Commun 2001;289(3):744-9.

4. Kodama N, Komuta K, Nanba H. Effect of Maitake (Grifola frondosa) $\mathrm{D}$-fraction on the activation of NK cells in cancer patients. J Med Food 2003;6(4):371-7.

5. Mitomi T, Tsuchiya S, Iijima N, Aso K, Suzuki K, Nishiyama K, et al. Randomized, controlled study on adjuvant immunochemotherapy with psk in curatively resected colorectal cancer. Dis Colon Rectum 1992;35(2):123-30.

6. Lindequist U, Niedermeyer TH, Jülich WD. The pharmacological potential of mushrooms. Evid Based Complement Alternat Med 2005;2(3):285-99.

7. Mothana RA, Jansen R, Jülich WD, Lindequist U. Ganomycins $\mathrm{A}$ and $\mathrm{B}$, new antimicrobial farnesyl hydroquinones from the basidiomycete Ganoderma pfeifferi. J Nat Prod 2000;63(3):416-8.

8. Mftah AE, Samiur SR, Alhassan FH, Al-Qubaisi MS, El Zowalaty ME, Webster TJ, et al. Physicochemical properties, cytotoxicity and antimicrobial activity of sulfated zirconia nanoparticles. Int J Nanomed 2015;10:765-74.

9. Song XR, Cai Z, Zheng Y, He G, Cui FY, Gong DQ, et al. Reversion of multidrug resistance by co-encapsulation of vincristine and verapamil in PLGA nanoparticles. Eur J Pharm Sci 2009;37(3-4):300-5.

10. Borchers AT, Krishnamurthy A, Keen CL, Meyers FJ, Gershwin ME. The immunobiology of mushrooms. Exp Biol Med (Maywood) 2008;233(3):259-76.

11. Valverde ME, Hernández-Pérez T, Paredes-López O. Edible mushrooms: Improving human health and promoting quality life. Int J Microbiol 2015;2015:376387.

12. Barros L, Baptista P, Ferreira IC. Effect of Lactarius piperatus fruiting body maturity stage on antioxidant activity measured by several biochemical assays. Food Chem Toxicol 2007;45(9):1731-7.

13. Sullivan R, Smith JE, Rowan NJ. Medicinal mushrooms and cancer therapy: Translating a traditional practice into Western medicine. Perspect Biol Med 2006;49(2):159-70.

14. Moro C, Palacios I, Lozano M, Arrigo MD, Guillamón E, Villares A, et al. Anti-inflammatory activity of methanolic extracts from edible mushrooms in LPS activated RAW 264.7 macrophages. Food Chem 2012;130(2):350-5.

15. Kohno K, Miyake M, Sano O, Tanaka-Kataoka M, Yamamoto S, KoyaMiyata S, et al. Anti-inflammatory immunomodulatory properties of 2-amino-3H-phenoxazin-3-one. Biol Pharm Bull 2008;31(10):1938-45.

16. Jose N, Ajith TA, Janardhanan KK. Methanol extract of the oyster mushroom, Pleurotus florida, inhibits inflammation and platelet aggregation. Phytoher Res 2004;18(1):43-6.

17. Lin WW, Karin M. A cytokine-mediated link between innate immunity, inflammation, and cancer. J Clin Invest 2007;117:1175-83.

18. Kim HG, Yoon DH, Kim CH, Shrestha B, Chang WC, Lim SY, et al. Ethanol extract of inonotus obliquus inhibits lipopolysaccharideinduced inflammation in RAW 264.7 macrophage cells. J Med Food 2007;10(1):80-9.

19. Cheung LM, Cheung PC, Ooi VE. Antioxidant activity and total phenolics of edible mushroom extracts. Food Chem 2003;81(2):249-55.

20. Kim MY, Seguin P, Ahn JK, Kim JJ, Chun SC, Kim EH, et al.
Phenolic compound concentration and antioxidant activities of edible and medicinal mushrooms from Korea. J Agric Food Chem 2008;56(16):7265-70

21. Yu YS, Hsu CL, Yen GC. Anti-inflammatory effects of the roots of Alpinia pricei Hayata and its phenolic compounds. J Agric Food Chem 2009;57(17):7673-80.

22. Solak MH, Ișiloğlu M, Gücin F. Macrofungi of İzmir province. Turk J Bot 1999;23:383-90.

23. Onbasili D, Celiki GY, Katircioglu H, Narin I. Antimicrobial, antioxidant activities and chemical composition of Lactarius deliciosus (L.) Collected from Kastamonu province of Turkey. (Kastamonu Bölgesinden Toplanan Lactarius deliciosus (L.)' in Antimikrobiyal, Antioksidan Aktiviteleri ve Kimyasal). Kastamonu Univ J Forest Fac 2015;15(1):98-103.

24. Kabir Y, Kimura S. Dietary mushrooms reduce blood pressure in spontaneously hypertensive rats (SHR). J Nutr Sci Vitaminol (Tokyo) 1989;35(1):91-4.

25. Ozen T, Darcan C, Aktop O, Turkekul I. Screening of antioxidant, antimicrobial activities and chemical contents of edible mushrooms wildly grown in the black sea region of Turkey. Comb Chem High Throughput Screen 2011;14(2):72-84.

26. Demirbas A. Concentrations of 21 metals in 18 species of mushrooms growing in the East Black Sea region. Food Chem 2001;75(4):453-7.

27. Rancic A, Kosanic M, Rankovic B, Stanojkovic T. Evaluation of metal concentration and antioxidant, antimicrobial, and anticancer potentials of two edible mushrooms Lactarius deliciosus and Macrolepiota procera. J Food Drug Anal 2016;24(3):477-84.

28. Mau JL, Chang CN, Huang SJ, Chen CC. Antioxidant properties of methanolic extracts from Grifola frondosa, Morchella esculenta and Termitomyces albuminosus mycelia. Food Chem 2004;87(1):111-8

29. Jayakumar T, Thomas PA, Sheu JR, Geraldine P. In-vitro and in-vivo antioxidant effects of the oyster mushroom Pleurotus ostreatus. Food Res Int 2011;44(4):851-61.

30. Ferreira IC, Baptista P, Vilas-boas M, Barros L. Free-radical scavenging capacity and reducing power of wild edible mushrooms from northeast Portugal: Individual cap and stipe activity. Food Chem 2007;100(4):1511-6.

31. Elmastas M, Isildak O, Turkekul I, Temur N. Determination of antioxidant activity and antioxidant compounds in wild edible mushrooms. J Food Compos Anal 2007;20(3-4):337-45.

32. Choi Y, Lee SM, Chun J, Lee HB, Lee J. Influence of heat treatment on the antioxidant activities and polyphenolic compounds of Shiitake (Lentinus edodes) mushroom. Food Chem 2006;99(2):381-7.

33. Alvarez-Parrilla E, de la Rosa LA, Martínez NR, Aguilar GA. Total phenols and antioxidant activity of commercial and wild mushrooms from Chihuahua, Mexico. Cien Tecnol Aliment 2007;5(5):329-34.

34. Benedict RG, Brady LR. Antimicrobial activity of mushroom metabolites. J Pharm Sci 1972;61(11):1820-2.

35. Iwalokun DK, Usen BA, Otunba AA, Olukoya DK. Comparative phytochemical evaluation, antimicrobial and antioxidant properties of Pleurotus ostreatus. Afr J Biotechnol 2007;6(15):1732-9.

36. Yang S, Jin L, Ren X, Lu J, Meng Q. Optimization of fermentation process of Cordyceps militaris and antitumor activities of polysaccharides in vitro. J Food Drug Anal 2014;22(4):468-76.

37. Dulger B, Yilmaz F, Gucin F. Antimicrobial activity of some Lactarious species. Pharm Biol 2002;40(4):304-6.

38. Ding X, Hou Y, Hou W. Structure feature and antitumor activity of a novel polysaccharide isolated from Lactarius deliciosus Gray. Carbohydr Polym 2012;89(2):397-402.

39. Ooi VE, Liu F. Immunomodulation and anti-cancer activity of polysaccharide-protein complexes. Curr Med Chem 2000;7(7):715-29.

40. Luo H, Mo M, Huang X, Li X, Zhang K. Coprinus comatus: A basidiomycete fungus forms novel spiny structures and infects nematode. Mycologia 2004;96(6):1218-24.

41. Redhead SA, Vilgalys R, Moncalvo JM, Johnson J, Hopple JS Jr. Coprinus Pers. and the disposition of Coprinus species sensu lato. Taxon 2001;50(1):203-4.

42. Zaidman BZ, Wasser SP, Nevo E, Mahajna J. Coprinus comatus and Ganoderma lucidum interfere with androgen receptor function in LNCaP prostate cancer cells. Mol Biol Rep 2008;35:107-17.

43. Ozalp FO, Canbek M, Yamac M, Kanbak G, Van Griensven LJ, Uyanoglu $\mathrm{M}$, et al. Consumption of Coprinus comatus polysaccharide extract causes recovery of alcoholic liver damage in rats. Pharm Biol 2014;52(8):994-1002.

44. Wasser SP. Novel Coprinus comatus and Tremella mesenterica Mushroom Strains, Products and Extracts There of and Compositions Comprising Them; 2010. 
45. Stojkovic D, Reis FS, Barros L, Glamoclija J, Ciric A, van Griensven LJ, et al. Nutrients and non-nutrients composition and bioactivity of wild and cultivated Coprinus comatus (O.F.Müll.) Pers. Food Chem Toxicol 2013;59:289-96.

46. Moglad E, Sadabaai AM. Screening of antimicrobial activity of wild mushrooms from Khartoum state of Sudan. Microbiol J 2012;2(2):64-9.

47. Kalaw SP, Albinto RF. Functional activities of Philippine wild strain of Coprinus comatus (O.F.Müll.: Fr.) Pers and Pleurotus cystidiosus O. K. Miller grown on rice straw based substrate formulation. Mycosphere 2014;5(5):646-55.

48. Srivastava MP, Sharma N. Antimicrobial activities of basidiocarp of some basidiomycetes strains against bacteria and fungi. J Mycol Plant Pathol 2011;41(2):332-4.

49. Small EJ, Roach M $3^{\text {rd }}$. Prostate-specific antigen in prostate cancer: A case study in the development of a tumor marker to monitor recurrence and assess response. Semin Oncol 2002;29(3):264-73.

50. Rouhana-Toubi A, Wasser SP, Agbarya A, Fares F. Inhibitory effect of ethyl acetate extract of the Shaggy Inc. cap medicinal mushroom, Coprinus comatus (Higher Basidiomycetes) fruit bodies on cell growth of human ovarian cancer. Int J Med Mushrooms 2013;15(5):457-70.

51. Bourbon AI, Cerqueira MA, Vicente AA. Encapsulation and controlled release of bioactive compounds in lactoferrin-glycomacropeptide nanohydrogels: Curcumin and caffeine as model compounds. J Food Eng 2016;180:110-9.

52. Couvreur P, Kante B, Grislain L, Roland M, Speiser P. Toxicity of polyalkylcyanoacrylate nanoparticles II: Doxorubicin-loaded nanoparticles. J Pharm Sci 1982;71(7):790-2.

53. Levy RJ, Labhasetwar V, Song C. Nanoparticle drug delivery systems. Adv Drug Del Rev 1997;24(1):63-85.

54. Almeida AJ, Souto E. Solid lipid nanoparticles as a drug delivery system for peptides and proteins. Adv Drug Deliv Rev 2007;59(6):478-90.

55. Fundarò A, Cavalli R, Bargoni A, Vighetto D, Zara GP, Gasco MR. Non-stealth and stealth solid lipid nanoparticles (SLN) carrying doxorubicin: Pharmacokinetics and tissue distribution after i.v. administration to rats. Pharmacol Res 2000;42(4):337-43.

56. Zhang Q, Shen Z, Nagai T. Prolonged hypoglycemic effect of insulinloaded poly butyl cyanoacrylate nanoparticles after pulmonary administration to normal rats. Int J Pharm 2001;218:75-80.

57. Papakostas D, Rancan F, Sterry W, Blume-Peytavi U, Vogt A. Nanoparticles in dermatology. Arch Dermatol Res 2011;303(8):533-50.

58. Nelson AM, Gilliland KL, Cong Z, Thiboutot DM 13-cis Retinoic acid induces apoptosis and cell cycle arrest in human SEB-1 sebocytes. J Invest Dermatol 2006;126(10):2178-89.

59. Messenger AG, Rundegren J. Minoxidil: Mechanisms of action on hair growth. Br J Dermatol 2004;150(2):186-94.

60. Takahashi T, Kamimura A. Cyclosporin a promotes hair epithelial cell proliferation and modulates protein kinase $\mathrm{C}$ expression and translocation in hair epithelial cells. $\mathrm{J}$ Invest Dermatol 2001;117(3):605-11.

61. Patel A, Prajapati P, Boghra R. Overview on application of nanoparticles in cosmetics. Asian J Pharm Sci Clin Res 2011;1:40-55.

62. Gibson AP, Hebden JC, Arridge SR. Recent advances in diffuse optical imaging. Phys Med Biol 2005;50(4):R1-43.

63. Gélis C, Girard S, Mavon A, Delverdier M, Paillous N, Vicendo P. Assessment of the skin photoprotective capacities of an organo-mineral broad-spectrum sunblock on two ex vivo skin models. Photodermatol Photoimmunol Photomed 2003;19(5):242-53.

64. Nohynek GJ, Schaefer H. Benefit and risk of organic ultraviolet filters. Regul Toxicol Pharmacol 2001;33(3):285-99.

65. Kumar P, Kulkarni PK, Srivastava A. Pharmaceutical application of nanoparticles in drug delivery system. J Chem Pharm Res 2015;7:703-12.

66. Celardo I, Pedersen JZ, Traversa E, Ghibelli L. Pharmacological potential of cerium oxide nanoparticles. Nanoscale 2011;3(4):1411-20.

67. Celardo I, Traversa E, Ghibelli L. Cerium oxide nanoparticles: A promise for applications in therapy. J Exp Ther Oncol 2011;9(1):47-51.

68. Das S, Dowding JM, Klump KE, McGinnis JF, Self W, Seal S. Cerium oxide nanoparticles: Applications and prospects in nanomedicine. Nanomedicine (Lond) 2013;8(9):1483-508.

69. Heckert EG, Karakoti AS, Seal S, Self WT. The role of cerium redox state in the SOD mimetic activity of nanoceria. Biomaterials 2008;29(18):2705-9.

70. Xue Y, Luan Q, Yang D, Yao X. Direct evidence for hydroxyl radical scavenging activity of cerium oxide nanoparticles. J Phys Chem C 2011;115:4433-8.

71. Dowding JM, Dosani T, Kumar A, Seal S, Self WT. Cerium oxide nanoparticles scavenge nitric oxide radical (?NO). Chem Commun
(Camb) 2012;48(10):4896-8.

72. Pirmohamed T, Dowding JM, Singh S, Wasserman B, Heckert E, Karakoti AS, et al. Nanoceria exhibit redox state-dependent catalase mimetic activity. Chem Commun (Camb) 2010;46:2736-8.

73. Perez JM, Asati A, Nath S, Kaittanis C. Synthesis of biocompatible dextran-coated nanoceria with $\mathrm{pH}$-dependent antioxidant properties. Small 2008;4(5):552-6.

74. Popov AL, Popova NR, Ivanov VK, Selezneva II, Akkizov AY. Cerium oxide nanoparticles stimulate proliferation of primary mouse embryonic fibroblasts in vitro. Mater Sci Eng 2016;68:406-13.

75. Chen J, Patil S, Seal S, McGinnis JF. Rare earth nanoparticles prevent retinal degeneration induced by intracellular peroxides. Nat Nanotechnol 2006;1:142-50.

76. Merchant S, Ellison A, Fry R. Engineered oxide nanoparticles protect against neuronal damage associated with in vitro trauma. J Neurotrauma 2009; 10:1105.

77. Estevez AY, Pritchard S, Harper K, Aston JW, Lynch A, Lucky JJ, et al. Neuroprotective mechanisms of cerium oxide nanoparticles in a mouse hippocampal brain slice model of ischemia. Free Radic Biol Med 2011;51(6):1155-63.

78. Cimini A, D’Angelo B, Das S, Gentile R, Benedetti E, Singh V, et al. Antibody conjugated PEGylated cerium oxide nanoparticles for specific targeting of $\mathrm{Ab}$ aggregates modulate neuronal survival pathways. Acta Biomater 2012;8(6):2056-67.

79. Falone S, D'Angelo B, Santucci S, Benedetti E, Di Loreto S, Phani RA. Cerium oxide nanoparticles trigger neuronal survival in a human Alzheimer disease model by modulating BDNF pathway. Curr Nanosci 2009;5:167-76.

80. Zhou X, Xu W, Liu G, Panda D, Chen P. Size-dependent catalytic activity and dynamics of gold nanoparticles at the single-molecule level. J Am Chem Soc 2010;132(1):138-46.

81. Rothenberg G. Catalysis: The best of both worlds. Nat Chem 2010;2(1):9-10.

82. El-Sayed MA, Narayanan R. Shape-dependent catalytic activity of platinum nanoparticles in colloidal solution. Nano Lett 2004;4(7):1343-8

83. Hamasaki T, Kashiwagi T, Imada T, Nakamichi N, Aramaki S, Toh K, et al. Kinetic analysis of superoxide anion radical-scavenging and hydroxyl radical-scavenging activities of platinum nanoparticles. Langmuir 2008;24(4):7354-64.

84. Kajita M, Hikosaka K, Iitsuka M, Kanayama A, Toshima N, Miyamoto Y. Platinum nanoparticle is a useful scavenger of superoxide anion and hydrogen peroxide. Free Radic Res 2007;41(6):615-26.

85. Yoshihisa Y, Zhao QL, Hassan MA, Wei ZL, Furuichi M, Miyamoto Y, et al. SOD/catalase mimetic platinum nanoparticles inhibit heatinduced apoptosis in human lymphoma U937 and HH cells. Free Radic Res 2011;45(3):326-35.

86. Caputo F, De Nicola M, Ghibelli L. Pharmacological potential of bioactive engineered nanomaterials. Biochem Pharmacol 2014:92:112-30.

87. Onizawa S, Aoshiba K, Kajita M, Miyamoto Y, Nagai A. Platinum nanoparticle antioxidants inhibit pulmonary inflammation in mice exposed to cigarette smoke. Pulm Pharmacol Ther 2009;22(4):340-9.

88. Kim J, Shirasawa T, Miyamoto Y. The effect of TAT conjugated platinum nanoparticles on lifespan in a nematode Caenorhabditis elegans model. Biomaterials 2010;31(22):5849-54

89. Kim J, Takahashi M, Shimizu T, Shirasawa T, Kajita M, Kanayama A, et al. Effects of a potent antioxidant, platinum nanoparticle, on the lifespan of Caenorhabditis elegans. Mech Ageing Dev 2008; 129(6):322-31.

90. Clark A, Zhu A, Sun K, Petty HR. Cerium oxide and platinum nanoparticles protect cells from oxidant-mediated apoptosis. J Nanopart Res 2011;13(10):5547-55.

91. Brown AS, Hargreaves JS. Sulfated metal oxide catalysts. Green Chem 1999;1(1):17-20.

92. Clark JH. Solid acids for green chemistry. Acc Chem Res 2002;35(9):791-7.

93. Figueras F, Delahay G, Ensuque E, Coq B. Selective catalytic reduction of nitric oxide by-decane on $\mathrm{Cu} /$ Sulfated-zirconia catalysts in oxygen-rich atmosphere: Effect of sulfur and copper contents. J Catal 1998;175(1):7-15.

94. Farrera C, Fadeel B. It takes two to tango: Understanding the interactions between engineered nanomaterials and the immune system. Eur J Pharm Biopharm 2015;95:3-12.

95. Sica A, Mantovani A. Macrophage plasticity and polarization: In vivo veritas. J Clin Invest 2012;122(3):787-95.

96. Jones SW, Roberts RA, Robbins GR, Perry JL, Kai MP, Chen K, et al. 
Nanoparticle clearance is governed by Th1/Th2 immunity and strain background. J Clin Invest 2013;123(7):3061-73.

97. Witasp E, Shvedova A, Kagan V, Fadeel B. Single-walled carbon nanotubes impair human macrophage engulfment of apoptotic cell corpses. Inhal Toxicol 2009;21:131-6.

98. Lundborg M, Dahlén S, Johard U, Gerde P, Jarstrand C, Camner P, et al. Aggregates of ultrafine particles impair phagocytosis of microorganisms by human alveolar macrophages. Environ Res 2006;100:197-204.

99. Kodali V, Littke MH, Tilton SC, Teeguarden JG, Shi L, Frevert CW, et al. Dysregulation of macrophage activation profiles by engineered nanoparticles. ACS Nano 2013;7:6997-7010.

100. Banchereau J, Steinman RM. Dendritic cells and the control of immunity. Nature 1998;392:245-52.

101. Laverny G, Casset A, Purohit A, Schaeffer E, Spiegelhalter C, de Blay F. Immunomodulatory properties of multi-walled carbon nanotubes in peripheral blood mononuclear cells from healthy subjects and allergic patients. Toxicol Lett 2013;217:91-101.

102. Tkach A, Yanamala N, Stanley S, Shurin M, Shurin G, Kisin E, et al. Graphene oxide, but not fullerenes, targets immunoproteasomes and suppresses antigen presentation by dendritic cells. Small 2013;9:1686-90.

103. Dobrovolskaia MA, McNeil SE. Immunological properties of engineered nanomaterials. Nat Nanotechnol 2007;2(8):469-78.

104. Mitchell LA, Lauer FT, Burchiel SW, McDonald JD. Mechanisms for how inhaled multiwalled carbon nanotubes suppress systemic immune function in mice. Nat Nanotechnol 2009;4(7):451-6.

105. Singh A, Nie H, Ghosn B, Qin H, Kwak LW, Roy K. Efficient modulation of T-cell response by dual-mode, single-carrier delivery of cytokine-targeted siRNA and DNA vaccine to antigen-presenting cells. Mol Ther 2008;16(12):2011-21.

106. Frick S, Bacher N, Baier G, Mailänder V, Landfester K, Steinbrink K. Functionalized polystyrene nanoparticles trigger human dendritic cell maturation resulting in enhanced $\mathrm{CD}^{4+} \mathrm{T}$ cell activation. Macromol Biosci 2012;12:1637-47.

107. Fallarini S, Paoletti T, Battaglini CO, Ronchi P, Lay L, Bonomi R, et al. Factors affecting $\mathrm{T}$ cell responses induced by fully synthetic glyco-gold-nanoparticles. Nanoscale 2013;5(1):390-400.

108. Schanen BC, Karakoti AS, Seal S, Drake DR $3^{\text {rd }}$, Warren WL, Self WT. Exposure to titanium dioxide nanomaterials provokes inflammation of an in vitro human immune construct. ACS Nano 2009;3:2523-32.

109. Bhattacharya K, Andón FT, El-Sayed R, Fadeel B. Mechanisms of carbon nanotube-induced toxicity: Focus on pulmonary inflammation. Adv Drug Deliv Rev 2013;65:2087-97. 